\title{
A comparative-philosophical perspective on divine hiddenness in the Hebrew Bible
}

\begin{tabular}{|c|}
\hline \\
\hline $\begin{array}{l}\text { Affiliation: } \\
{ }^{1} \text { Faculty of Humanities, } \\
\text { North-West University, Vaal } \\
\text { Campus, South Africa }\end{array}$ \\
\hline $\begin{array}{l}\text { Correspondence to: } \\
\text { Jaco Gericke }\end{array}$ \\
\hline $\begin{array}{l}\text { Email: } \\
\text { 21609268@nwu.ac.za }\end{array}$ \\
\hline $\begin{array}{l}\text { Postal address: } \\
\text { PO Box 1174, Vanderbijlpark } \\
\text { 1900, South Africa }\end{array}$ \\
\hline $\begin{array}{l}\text { Dates: } \\
\text { Received: } 06 \text { Dec. } 2014 \\
\text { Accepted: } 04 \text { May } 2015 \\
\text { Published: } 10 \text { June } 2015\end{array}$ \\
\hline $\begin{array}{l}\text { How to cite this article: } \\
\text { Gericke, J., 2015, 'A } \\
\text { comparative-philosophical } \\
\text { perspective on divine } \\
\text { hiddenness in the Hebrew } \\
\text { Bible', Verbum et Ecclesia } \\
36(1), \text { Art. \#1400, } 8 \text { pages. } \\
\text { http://dx.doi.org/10.4102/ } \\
\text { ve.v36i1.1400 }\end{array}$ \\
\hline $\begin{array}{l}\text { Copyright: } \\
\text { C 2015. The Authors. } \\
\text { Licensee: AOSIS } \\
\text { OpenJournals. This work is } \\
\text { licensed under the Creative } \\
\text { Commons Attribution } \\
\text { License. }\end{array}$ \\
\hline
\end{tabular}

This study is concerned with the problem of divine hiddenness as it has taken shape in analytic philosophy of religion over the past two decades. More specifically, the interest lies with providing a comparative-philosophical perspective on the most fundamental assumptions of the problem in certain formulations and its responses against the backdrop of diverse yet related data in the Hebrew Bible. In doing so the aim is not to justify or critique any particular biblical or philosophical perspective on divine hiddenness but simply to identify and clarify some crucial differences in various relevant conceptual backgrounds.

Intradisciplinary and/or interdisciplinary implications: By way of pointing out a number of similarities and differences between concepts of divine hiddenness in the theologies of the Hebrew Bible and in a specific formulation thereof in analytic philosophy of religion, this article not only reveals some neglected specifics of the historical variability of an important theological idea but also suggests taking caution when appealing to alleged biblical precursors to contemporary philosophical-theological problems.

\section{Introduction}

In the study of the Hebrew Bible (HB), the concept of divine hiddenness is a familiar theological theme. Familiar studies that have approached the topic from a variety of linguistic, literary, historical, social-scientific and theological perspectives include, inter alia, Perlitt (1971:367-382), Terrien (1978), Balentine (1983), Brueggemann (1997:333-358) and Sæbø (2000:43-55). As far as subthemes are concerned, these include, amongst others, grammatical aspects of Biblical Hebrew words for divine hiddenness, the concept of the deity's 'hiding the face', the relationship of divine hiddenness to sin, a personal existential crisis as a result of divine hiddenness, general biblical notions of divine presence or absence, the deity's hiddenness in the context of sacred (cultic) spaces, related modes of divine revelation, divine providence, divine inscrutability, dual causality, and the so-called problem of evil.

As for examples from the text, one of the most obvious polemical instances of a concern with divine hiddenness in the HB is found in interrogative demands such as 'Where is/are the/their/ your god(s)?' (Dt 32:37; 2 Ki 2:14; 2 Ki 18:34 [cf. Is 36:19; Ps 42:3, 10; Ps 79:10; Ps 115:2; Jr 2:28; Jl 2:17; Mi 7:10; Ml 2:17]). This request to account for a 'deus absconditus' was, however, not limited to the world of ancient Israel. Not only are there many ancient Near Eastern parallels to the motif of a hidden god (see the many instances in the entries of the DDD [eds. Van der Toorn, Van der Horst \& Becking 1999:passim]). In addition, the problem was a popular theological conundrum in the history of Judeo-Christian theology (e.g. in Christian mysticism's reflection on 'the dark night of the soul'; cf. Schellenberg 1993:299-300).

More recently a host of publications on divine hiddenness has seen the light, particularly within analytic (theistic or atheistic) philosophy of religion (cf. eds. Howard-Snyder \& Moser 2001). To be sure, divine hiddenness is also a topic of interest in some circles of Continental philosophy. Yet stereotypical textbooks entitled Philosophy of religion in English-speaking countries (mainly the United States and the United Kingdom) all tend to trace back the recent interest in divine hiddenness to the argument originally formulated Schellenberg (1993). Most subsequent related research in analytic philosophy of religion was a response to that, as Schellenberg (2010b) noted more recently:

All in all, it is clear that the hiddenness problem has become a focus of exciting and lively discussion in philosophy of religion. Featuring a discussion less than two decades old, this whole area is ripe for new developments. (p. 1)

So popular is the problem of divine hiddenness currently within this philosophical subfield and within the analytic tradition that it is often discussed in conjunction with other arguments for and against atheism, especially arguments from the problem of evil (from which it is sometimes 
distinguished; cf. e.g. Murray \& Taylor 2010:308-317). In that context, it is also known as the argument from (reasonable, nonculpable, or nonresistant) unbelief (cf. Lehe 2004: 159-174). In a relatively recent reformulation by Schellenberg (2011:165-166), an argument from divine hiddenness can therefore be construed to run as follows:

1. If no perfectly loving God exists, then God does not exist.

2. If a perfectly loving God exists, then there is a God who is always open to a personal relationship with each human person.

3. If there is a God who is always open to personal relationship with each human person, then no human person is ever non-resistantly unaware that God exists.

4. If a perfectly loving God exists, then no human person is ever non-resistantly unaware that God exists (from 2 and 3).

5. Some human persons are non-resistantly unaware that God exists.

6. No perfectly loving God exists (from 4 and 5).

7. God does not exist (from 1 and 6).

Numerous other formulations of the hiddenness problem have been put forward, both by those who seek to advance and/or criticise the argument from unbelief (cf. Aijaz \& Weidler 2007:1-23; Drange 1998; eds. Howard-Snyder \& Moser 2001:7; Schellenberg 2005a:201-215; Schellenberg 2005b:287-303). Of all that might be said of the whole discussion, what is most of interest to the present article is the fact that, in constructing the history of the problem of divine hiddenness, both Schellenberg and others have at times traced its historical roots to the HB. Thus according to Schellenberg (2010b):

First, notice that talk of 'Divine hiddenness' or the 'hiddenness of God' originates in contexts of unquestioning belief - think only of the Hebrew psalmist's laments. (p. 2)

The identification of the $\mathrm{HB}$ as representing the historical roots for the problem in its Judeo-Christian format is a typical assessment amongst some philosophers of religion. One popular example of alleged divine hiddenness in the text is said to be Psalm 22:1 (cf. Snyder \& Moser 2001b:7). References to verses from the Psalter are sometimes supplemented with quotes from the Prophets (e.g. Is 45:15) and from the wisdom literature (e.g. Job 23:1-17), the other two main corpuses where references to divine hiddenness occur (cf. Balentine 1983). Such appeals to the motif of divine hiddenness in the HB feature also in critics of the problem (cf. Murray \& Taylor 2010:308). In general, however, engagement by philosophers of religion with the $\mathrm{HB}$ on the problem of divine hiddenness seldom extends beyond brief remarks and tend not to involve in-depth comparative-philosophical analysis.

\section{The research problem and its assumptions}

The research problem of this study is concerned with the question of how assumptions and underlying concepts of divine hiddenness in the HB might differ from those in contemporary theistic and atheistic philosophy of religion.
In an attempt to flesh out some interesting contrasts, the following can be said to be the assumptions of the inquiry.

With regard to the $\mathrm{HB}$, it is not assumed that the $\mathrm{HB}$ contains only one view on any of the theological and philosophical topics related to the problem of divine hiddenness in philosophy of religion. It is also not assumed that the texts used as examples here represent some or other unified 'biblical' perspective on the matter. They are not to be seen as 'proof-texts' in an attempt to justify a particular theological point of view. The HB is much more complex with regard to its assumptions framing the subject of divine hiddenness than any given text could possibly suggest and as a whole the corpus contains conflicting evidence on the topic. The HB rarely speaks with 'one voice' so the contrasts being made are not as clear-cut as they are made to appear.

Granting all of this, of interest are exactly those examples of texts that seem to sit uneasily with some of the underlying notions in the premises and conclusion of the argument as reconstructed by Schellenberg (2011:165-166). As a result, it is inevitable that the discussion might lack more specific biblical illustrations in some of the paragraphs so that differences of viewpoint within the HB itself might seem less nuanced than they actually are. Hence, cognizance should be taken of the particular selective manner of structuring the presentation (also constrained by spatial limits). This state of affairs need not be seen as detrimental to the case being made, given its primary concern, namely of showing instances where the $\mathrm{HB}$ contains assumptions that differ from those found in the stereotypical argument from divine hiddenness.

With regard to the use of Schellenberg's version(s) of the argument from divine hiddenness, it might be assumed that in its comparative interest this article relies too heavy on the work of this particular analytic philosopher (and ignores other positions in analytic and Continental philosophy of religion). However, it should be noted that it is not assumed that his work represents the only, latest, best or even most representative current take on the topic of divine hiddenness in all currents of philosophy of religion. The reason that the comparisons made below refer mainly to the formulation by Schellenberg is that his construction of the argument from unbelief is often still considered in much of mainstream analytic philosophy of religion to provide a classic introductory and standard point of orientation to some of the philosophical issues involved in the theological puzzle.

In comparing ideas from some parts of the $\mathrm{HB}$ to similar or different ones in some theories in philosophy of religion it is not assumed that there are only differences and contradictions between the two fields. Some significant differences are merely pointed out for interest's sake. However, this is not done to show that the HB is of necessity alien or amenable to philosophical thinking or to facilitate or prevent dialogue between the two fields from occurring. It is also not done in the belief that any of either the biblical or philosophical perspectives are superior in merit vis-à-vis the other. It is purely an exercise in selective, experimental, comparative 
and descriptive philosophy of religion, with some possible tensions between modern and ancient notions of divine hiddenness as the central concern.

In sum, whilst based on a selection of stereotypes both from philosophy of religion and the $\mathrm{HB}$, it is assumed that the essentialist, ideologically motivated and developmentalist assumptions often found in biblical-theological and religious-philosophical discussions of the problem of divine hiddenness are conceptually problematic given the complexity and nuanced discourses evident in both the HB and in philosophy of religion (cf. Albertz 1994; Brueggemann 1997; Gericke 2012; Gerstenberger 2002; Leuenberger 2011).

\section{Objectives and method}

Although situated within the context of HB scholarship, the objective of this study is to neither repeat nor get involved in the ongoing discussion of divine hiddenness in the $\mathrm{HB}$ within biblical theology (cf. Balentine 1983; Brueggemann 1997:333-358; Perlitt 1971:367-382; Sæbø 2000:43-55; Terrien 1978). Instead, the purpose of this article is to put forward a new perspective on some of the issues in the discussion of the problem of divine hiddenness via comparative philosophy of religion. Special attention will be given to some of the takenfor-granted assumptions in Schellenberg's reformulation of the argument from unbelief that can be construed as being anachronistic in some contexts of the $\mathrm{HB}$, despite the popular belief that the latter is also an example of the historical roots of the problem. The aim is not to endorse or dismiss any particular biblical or philosophical perspective on divine hiddenness but simply to note the existence of some of the different basic assumptions possibly underlying related philosophical-theological themes.

\section{Some philosophical and biblical assumptions about divine hiddenness compared}

First of all, according to both Schellenberg's and others' formulations of the argument of divine hiddenness, perhaps the most obvious assumption is that, if there is a god, there is only one god (cf. Schellenberg 2005a:287). It is with reference to this idea that the HB not only agrees with in some texts but also differs from in others. On the one hand, in some religiohistorical contexts the concept of generic divinity in the $\mathrm{HB}$ exhibits extensions that include not only Yhwh, but also other supernatural and preternatural beings; for example, other sons of the gods, the dead, the divine council, demons, the king, certain humans, superlative natural phenomena, power, et cetera (e.g. Gn 1, 11, 23:6; Ex 4:16, 7:1, 12:12; Lv 16; Dt 32:8 [LXX]; Jdg 11:24; 1 Sm 28:17; Is 14; Hab 1:12; Pss 45:6, 58:1-2, 82:1-6; Ps 89, 97:7; Job 38:4, and passim; cf. Gericke 2012:352). On the assumption that there is only one god who is at the heart of the problem of divine hiddenness, the $\mathrm{HB}$ thus actually presents us with a somewhat more complex picture. On the other hand, and with reference to biblical instances of affirming one deity, the use of the term 'monotheism' for the technical characterisation of the nature of theism involved in such discourses has elicited great controversy amongst HB scholars (cf. Frevel 2013 for a recent overview). In short, whilst some texts in the $\mathrm{HB}$ have been read as assuming that there is only one god (in a 'monotheistic' sense), others are recognised as not fitting into a somewhat anachronistic bracket and often do contain alternative theistic conceptions of reality. But that is to be expected, for as with all the other arguments to follow, the $\mathrm{HB}$ contains contradictory viewpoints on the given topic and speaks with more than one voice.

The second taken-for-granted assumption in many divine hiddenness arguments is that, if there is a god, it can be universally accepted that this god's (perhaps greatest) desire is that a certain species of creatures (i.e. humans) should affirm its existence (cf. Dougherty \& Poston 2007:183-198). This assumption can be seen as presumptuous from a comparative religious perspective, as was pointed out by McKim (2001). It is also presumptuous in some contexts of the HB, not because belief in the existence of Yhwh was not considered important but because nowhere is such a cognitive disposition emphasised and prioritised in so many words. Mere belief in the existence of Yhwh or the gods is mostly taken-for-granted, yet nowhere noted as a primary moral or intellectual virtue. Even confessions of Yhwh as the 'living god' are not so much the propositional language of philosophy but encountered in contexts of passionate and assertive affirmation (e.g. Dt 5:26; 2 Ki 9:16; and passim). Complicating the picture somewhat more, in texts which have been said to assume monolatry rather than monotheism (both terms are controversial), belief in Yhwh's existence only was not deemed to be universally required by the divine, as divine-hiddenness arguments presuppose with reference to 'God' (cf. e.g. Jdg 11:24). In some texts, other nations were not even assumed to have knowledge of Yhwh, without it being a philosophical problem (cf. e.g. Ps 147:20). Another text even assumes that each nation will and should walk in the ways of its own god (Mi 4:5). Even when universal affirmation of Yhwh's rule is affirmed, the HB still explicitly only refers to what some philosophers of religion call belief in (vis-à-vis belief that). That is, whilst belief in the existence of Yhwh is assumed, the only type of belief mentioned is a form of basic trust (rather than as intellectual achievement) (cf. e.g. Is 26:3; Pss 13:5, 22:4-5, 33:21, 40:4, 56:3-4, 112:7; Pr 3:5 and passim). Finally, the acceptable range of and room for doubt in many forms of spirituality in the $\mathrm{HB}$ are often forgotten by and hardly the cardinal sin presupposed in clinically formulated divine hiddenness arguments (e.g. in the 'faith' of Abraham, Moses, Job, Jeremiah, et al.; cf. Davidson 1983).

In a third assumption concerning divine hiddenness, and related to the previous one, the problematic is often defended most passionately in the context of atheism, whether positive or negative (cf. Schellenberg 2004:30-41). When compared to related assumptions in the HB, however, one may note that, on the one hand, many characters were assumed not to know Yhwh, yet were not assumed to be atheists (for they either believed in their own gods or did believe in Yhwh's existence but not in his power or lordship). 
The fact is that positive, strong and broad atheism (technical typological philosophical classifications of the contemporary phenomenon of denying the existence of all gods), is alien to almost all texts in the HB. Even in those texts where some sort of atheism might be assumed as present in the face of divine hiddenness (e.g. Pss 10, 14[53]; Ps 55:20b?; Pr 30?), HB exegetes are in disagreement as to whether the conceptual phenomenon referred to is in fact theoretical atheism, or rather only practical atheism, especially since the characters of the antagonists are also constructed as rebelling against the divine (thus perhaps presupposing antitheism or even misotheism, rather than atheism) (cf. Gericke 2012:351-357). The bottomline, hinted at here but discussed in more detail in the last point, is that in the $\mathrm{HB}$, divine hiddenness is generally not thought to warrant atheism.

A fourth assumption in many divine hiddenness arguments is that, if there is one god, this god is also only good (cf. Howard-Snyder 1996:433-453). By this is usually meant that God is 'perfectly loving' and that God is such 'by definition' (cf. Schellenberg 2005c:330-342). Yet also in relation to this topic the HB contains a diversity of assumptions. To be sure, Yhwh is certainly assumed to be as good and loving as an ancient Near Eastern god could be. Yet this was often not intended to deny that the deity could not also be the cause of evil (in a certain sense of the word). Whilst some texts do deny that Yhwh can be charged with being involved in the actualisation of evil (e.g. Ps 5:4), a closer look at the acts of Yhwh and at many confessions by characters in the texts shows that some authors of the HB had no problem connecting Yhwh in a causal manner simultaneously with both goodness and with the creation and/or catalysing of many metaphysical, moral and natural evils (cf. Crenshaw 2005 for an in-depth treatment of instances, as opposed to isolated verses like Is 45:7). Thus even though in philosophy of religion the problem of divine hiddenness relates to but can be distinguished from the problem of evil (cf. Schellenberg 2010a:45-60), the HB technically does not know of a problem of evil in the classical theistic philosophical sense. In contrast to the tastes of modern philosophical theism, many traditions of the HB did not assume a god must be perfectly loving (however this is meant) in order to be worthy of worship. In fact, in the HB as a whole, goodness and/or love were not assumed to be essential or necessary properties of generic divinity, that is, an entity like Yhwh could in theory lack the property of goodness and still be divine. What is more, ideas of divine goodness in the HB do not always mean precisely the same as popular modern philosophical notions of the concept of goodness; for example, in the HB divine goodness did not preclude never unjustly bringing harm to many an innocent person. This shows that many HB conceptions of divine goodness and love should for the sake of clarity also be contextualised (not relativised) against their own dystheistic backdrop.

Fifth, when it comes to divine properties denoting ability, a perusal of the philosophical literature will show that many arguments from divine hiddenness usually unfold along the lines of classical metaphysical theism's perfect-being theology (cf. Howard-Snyder 1996:433-453). It is often simply assumed that God qua god must be omnipotent, omniscient, omnipresent and so on. In this regard, whilst some texts in the $\mathrm{HB}$ can be read as assuming similar properties being instantiated on the part of Yhwh, others cannot. In the latter cases, of which there are many (although mostly implicit), Yhwh was not assumed to be able to do anything he wanted according to his nature, knew everything that could be known or be present in the same sense everywhere (cf. Fretheim 1982 for some examples of texts where Yhwh lacks omnipotence and omniscience; Fretheim was, however, less keen to admit the presence of texts denying divine omnipresence). In this way, distinct differences between the properties of God in Schellenberg's formulation of the philosophical problem of divine hiddenness and those in some alternative representations of deity in the HB should not be overlooked. Without implying that perfect-being theologies or instances of limited deity concepts in the HB are right or wrong (or better or worse than philosophical-theological ones), the different perspectives on the matter are simply to be noted here.

Sixth, the exemplary philosophical divine-hiddenness argument under consideration assumes that the deity wants not only to exist in relation to humans but also do so in a personal relationship with every human being (cf. Tucker 2008:67). In this regard, again we encounter a pluralism of perspectives in the HB. On the one hand, it cannot be denied that many texts in the HB do assume that Yhwh wanted to be in some sort of relationship with all people (e.g. Gn 1-11). On the other hand, different texts assume different things and the notion of an intimate personal relationship between the deity and all humans along evangelical Christian lines is often totally absent (even in individual lament Psalms, which were written for specific communities, e.g. Pss 23, 27, 42-43, 63, 103, 118, 119, 139, and passim; but most notably in Qohelet and also whenever the god relates personally only to the mediator between divinity and humanity - e.g. Moses, Samuel, Elijah, etc.). Even where an individual personal relationship with a god was assumed to exist, the biblical notions themselves were not so much derived from something similar to philosophical monotheism's personal god concept but from earlier ideas in the history of religion related to the context of family piety where it involved not so much a deity as sole creator of the universe but individual limited household gods. In the various sociological contexts for the construction of deity, the idea of a universal personal relationship between God and humans was also basically absent from the level of tribal and state theologies where Yhwh was more often than not constructed as a warrior and a king for whom a personal relationship with anything smaller than the collective and a selected few favourites was sometimes completely out of place (for a detailed theological discussion, cf. Gerstenberger 2002).

The seventh assumption in Schellenberg's argument identified here pertains to the historically variable meanings of the concept of divine hiddenness itself. In philosophy of religion, divine hiddenness can mean, inter alia, the 
passivity, absence or invisibility of the deity (cf. Schellenberg 2011:165-166). A basic assumption is that a hidden god is one who is not an obvious feature of reality (cf. Murray \& Taylor 2010:308). In the context of contemporary naturalist philosophies of religion, the divine is not assumed to be present in what can be constructed as purely natural, social and psychological processes (cf. Schellenberg 1993). Examples of what would then count as counterevidence are said to include extraordinary phenomena such as theophanies, auditions, signs and miracles, as opposed to ordinary and everyday states-of-affairs for which scientific explanations no longer require a god-hypothesis. By contrast, many texts in the HB assume Yhwh's acts and their effects (not his person) were present almost everywhere. Whilst some texts in the $\mathrm{HB}$ do deny the involvement of Yhwh in some domains (e.g. in texts where Yhwh is assumed not to be involved in Sheol or in some autonomous human actions, etc.), some other biblical theologies (e.g. some wisdom theologies) could also assume continual divine presence and participation in all that happens (cf. Brueggemann 1997:333-347). Examples include the belief that it is Yhwh who causes the weather, who creates political turmoil and who turns the hearts of people to make personal decisions in alignment with his will. In other words, where philosophers today see divine absence or hiddenness (or primitive, outdated and prescientific notions of divine presence), some texts in the HB often still assumed Yhwh's presence can be presupposed in mundane everyday purely 'natural' events. In addition, here the HB contains a multiplicity of alternate constructions of the relationship between Yhwh and the world in the text, so no generalisation on the $\mathrm{HB}$ as a whole is possible with reference to the topic under discussion in this paragraph.

Eighth, in terms of structural reasons for divine hiddenness in a theistic philosophical conception of divinity, it is often assumed to be due to otherness, transcendence, invisibility, incorporeality, holiness and so on (cf. eds. Howard-Snyder \& Moser 2001:passim; Schellenberg 1993:passim). When this is compared to some of the HB's references to a hidden god (or to the hidden [read: powerless] gods of other nations), one encounters both similarities and differences once again. Whilst Yhwh's person is for the most part not assumed to be physically visible or available, sometimes the reason the deity is constructed as 'hidden' only because Yhwh was assumed to be enthroned in heaven, which was, however, assumed to be inside the cosmos rather than being somewhere utterly otherworldly altogether (cf. Fretheim 1982:32). Many a HB perspective on structural reasons for divine hiddenness also presuppose that the cosmos functioned as a theocratic state characterised by some sort of apartheid between the divine and human worlds, two distinct natural realms that do not mix lest the cosmic order is disrupted (cf. Gn 6:1-4). This a typical ancient Near Eastern warrant for general divine absence (Van der Toorn 1999:353). In social-scientific terms, some texts assumed it to be more honourable for a god to be hidden than to be present-at-hand (cf. Is 45:15; Pr 25:1; Ec 3:11). In many cultic contexts the deity is often also constructed as 'hidden', albeit in the sacred space of a tabernacle or temple, the counterpart of a heavenly dwelling where it lives hidden so as to be away from the mass of the people, too much light and excessive noise (cf. Van der Toorn 1999:354). In yet others, Yhwh's own body is of necessity assumed to be hidden by light or a cloud or some other phenomenon, simply because it was assumed Yhwh either could not or did not want to be seen (cf. Sommer 2009:10). Additional possible reasons for divine hiddenness include the fact Yhwh, like other gods, were assumed to be in council, on a journey, asleep or meditating (cf. 1 Ki 18; Pss 44:24, 82; contra Fretheim 1982:22). On some occasions in the HB, the most explicit references to divine hiddenness associate the phenomenon with human sin, divine mystery, human and divine cognitive limitation (e.g. divine forgetfulness!) or affective aversion (Yhwh's rejection or lack of trust in people; cf. Num 12, where because Moses is said to be most trustworthy and therefore not in need of divine hiddenness in the form of obscurity in communication, as is the case with the qualitative difference of divine revelation between Moses and ordinary prophets). Again, whilst some structural reasons in the HB may overlap with those in apologies for divine hiddenness in philosophical theology, the pluralism of the biblical data does not allow for generalisations in the form of some unified biblical perspective on the matter.

Ninth, and related to the previous point, as far as personal or existential reasons and motives for divine hiddenness are concerned, a host of theodicies, defenses and responses has been put forward (cf. eds. Howard-Snyder \& Moser 2001:7). These include human fragility, divine respect for human free will, preventing obedience through fear, the possibility of human 'soul-making', facilitating relationship integrity, creaturely cognitive dysfunction, the prevention of spiritual problems, unknown goods, et cetera. Comparing this to various conflicting grounds for divine hiddenness in the $\mathrm{HB}$ we may note that some texts know nothing of these 'orthodox' explanations. To be sure, we do have texts that can be read as assuming something similar to what is found in these philosophical counterarguments. However, for the most part the contrast with such philosophical perspectives lies in those HB traditions according to which Yhwh can appear and talk directly to humans without any negative consequences (Abraham, Jacob, Moses, Samuel, Amos, et al.); or neglect to appear, without positive consequences (e.g. during the generations of slavery in Egypt). Also included are texts, amongst others, where:

- $\quad$ signs could be demanded from Yhwh (1 Ki 18; Is 38)

- the relationship between Yhwh and someone could even have been better if the deity was more forthcoming (e.g. Moses and Job)

- Yhwh cared little for human autonomy and free will and showed his power by hardening hearts exactly so as to prevent relationships with people (Ex 7-12; Is 6, 64)

- Yhwh wanted people to fear him so as to obey him (Ex 17; Ec 3:18-22)

- Yhwh simply did not want all people to know him personally (or in the same intimate manner as some chosen individuals (most texts). 
The fact here is that in the HB it is seldom suggested that divine hiddenness was good for spiritual growth, even in contexts where the protagonist has learned or proved something (e.g. in the case of Abraham, Moses, Elijah, Job, Habakuk, the psalmists, et al.). Often there do not seem to be unknown goods (besides a divine plan with an agenda for self-glorification or destruction of the other). Again, from the modern philosophical perspective on divine hiddenness under consideration in this article, these traditions in the HB (but not all others), represent a theologically alien state of affairs. Conversely, the philosophical assumptions justifying divine hiddenness are anachronistic in the context of many HB texts.

Tenth, the analogies used by most analytic philosophers of religion in discussing the divine human relationship are often drawn from familial or romantic settings. The deity is assumed to act like a contemporary and stereotypically functional western parent or committed and affectionate romantic lover. However, looking at the $\mathrm{HB}$, these metaphors for Yhwh, though parental and romantic relationship metaphors are present (particularly in the prophetic literature and in some theophoric personal names), the idea of Yhwh as father or lover is otherwise mostly absent. In other texts, the predominant roles or metaphors for Yhwh are not those of one who loves (whether via philia or eros) but one who has power to kill and make alive, who saves and destroys, et cetera (cf. e.g. Ex 4:11; 2 Ki 5:7; Is 45:7). Even in those contexts in the HB where Yhwh is cast in parental or romantic roles, be it as father or mother or husband, it should be remembered that in the HB's cultural milieu this involved dispositions toward the objects of affection (children and spouses) often quite different from what modern western people assume to be normal or acceptable as regards the status of the other, or in terms of parenting styles and in romantic etiquette. To be sure, the idea that the god of the HB was not a god of love as in the NT is a misconstrued reductionist stereotype (as if there was only one conception of deity in either testament). Yet the point here is that whilst Yhwh in the HB was often said to be a loving god, what this involved in a particular sociocultural context was not at all what modern philosophical attempts at providing analogies between God and parents or lovers had in mind.

The eleventh point follows on the aforementioned observations in that philosophical arguments from divine hiddenness often assume that the nature of religious language in the context of the problem is analogical (or metaphorical) (cf. eds. Howard-Snyder \& Moser 2001:passim; Schellenberg 1993:passim). When philosophical god-talk refers to divine hiding, for example, the language is not always taken literally in all of the details, as though there were a being of limited extension deliberately trying to evade human agents so as to remain undetected. However, whilst the HB also contains different perspectives also on the nature and meaning of divine hiddenness and certainly does employ metaphorical language in its god-talk at times, sometimes textual references to divine hiddenness (especially the hiding of the face) could initially and later unorthodoxly be understood in quite a literal sense. Thus, the hiding god was constructed as at times literally trying to avoid the presence of people, whether for personal or social reasons (as after the golden calf incident in Ex 32-34). One need only think of Yhwh hiding himself from humans whilst building the tower of Babel (Gn 11), of Yhwh trying to avoid Jacob seeing him (Gn 32), of Yhwh hiding his face from Moses in the rock (Ex 33), Yhwh being hidden from the people on Sinai (Ex 17-19), and of Yhwh's glory departing from the temple during the exile in the visions of Ezekiel. This much cannot be denied, despite the existence of alternative traditions and conceptions as well as variable grades of hiddenness in these HB's texts, particularly as the biblical data, for all its diversity, never assumes the kind of radical divine absence of the philosophical (atheistic) argument from divine hiddenness.

Twelfth, some divine hiddenness arguments depend on an assumed anthropology and eschatology not always present in the HB (cf. Drange 1998; eds. Howard-Snyder \& Moser 2001:passim; Schellenberg 1993); for example, the reason why some philosophers of religion assume a loving personal relationship with the divine to be important is that the possession thereof is held to be a necessary and sufficient condition for salvation on some sort of judgement day, for the avoidance of Hell, and for going to heaven as part of a beatific afterlife (hence notions of culpability). By contrast, the HB for the most part does not operate at all with a belief in an afterlife involving a final judgement based on the criterion of whether humans are in a loving, cognitively-believing, personal relationship with the deity. Various views of Sheol (or the afterlife) coexist in the $\mathrm{HB}$, often with contradictions in terms of the details; for example, different views of the geography of Sheol, of the fate of the individual in relation to Yhwh, of who lives on and how, of the nature of 'life' there, whether Yhwh is present, whether Yhwh is praised there, whether the dead can live again, whether Yhwh thinks of the dead, et cetera. Compare, for example, the concept of death (Dn 12:2 vis-à-vis in Ec 3:18-22, 9:10; or in the Psalter amongst Pss 6:5, 49:15, 73:24, 88:3-12, 139:8). Yet the soteriologies, cosmologies, anthropologies and eschatologies of later Christian theologies that the argument of Schellenberg presupposes are basically absent from the HB's variable constructions of Sheol. With reference to many $\mathrm{HB}$ contexts, therefore, the philosophical problem of divine hiddenness as a concern with the eternal fate of the individual after death in relation to different destinations could be seen as anachronistic.

Thirteenth and finally, irrespective of whether or not the argument from divine hiddenness is assumed to be a species of the problem of evil, in some philosophical circles it is also assumed to be an argument against the existence of God. By contrast, as hinted at earlier, conceptions of divine hiddenness in the HB are almost never a cause for doubting the existence of Yhwh (cf. however Pss 10:4, 14:1[53:1]; $\operatorname{Pr} 30: 1-4$ on some interpretations of these texts). On the contrary, in those contexts where divine hiddenness is a result of human sin it is in fact seen as evidence, not of divine absence but of divine action (contra Schellenberg 2010b:2). In other contexts, such as the suffering of a righteous person, 
the problem of divine hiddenness was for the most part only a cause for existential concern, not atheism. As such, divine hiddenness was a problem in the intellectual sense only in as much as it could result in theological perplexity as to divine motivation (cf. eds. Howard-Snyder \& Moser 2001:7). On other occasions, divine hiddenness in the HB could cause doubts regarding Yhwh's power, presence and, especially in polemical contexts, the existence or power of other gods (see Crenshaw 2005 for an extensive discussion of these themes). In short, divine hiddenness in the HB was not seen as problematic for the same reasons it is construed as such in some circles of theistic and atheistic analytic philosophy of religion. Whereas in the latter cases, divine hiddenness is thought to potentially warrant doubts as to the activity - if not the very existence - of God, the hiddenness of Yhwh in the $\mathrm{HB}$, despite being constructed in different forms, was almost always assumed to be part of what was proper to the mysterious divine nature, and therefore in a way a sign of Yhwh's status as a living deity.

\section{Conclusion}

Much more could be said both about philosophy of religion and the $\mathrm{HB}$ on the topic of divine hiddenness; for example, one could have focussed on different aspects of the particular matters discussed, or have engaged with different philosophers and philosophical traditions with different viewpoints on the topic than Schellenberg. Yet for present purposes and given the spatial limitations of a single article the idiosyncratic introductory comparative overview presented here must suffice for the purpose it was drafted. The bottom line is that when it comes to assumptions about divine hiddenness, as was argued in an intentionally nuanced and qualified manner, the HB sometimes presents us with essentially alien conceptual backgrounds vis-à-vis what, from some biblical perspectives, could be construed as anachronistic notions found in Schellenberg and subsequent rejoinders in contemporary theistic and atheistic analytic philosophy of religion.

These findings should not be taken to imply, however, some sort of result, such as that philosophical concerns are wrongheaded, or that there should be a return to some or other 'biblical' perspective on divine hiddenness. Nor does it imply that philosophical views are correct and that the HB's ideas must be done away with. The only point of the whole exercise in brief comparison was to create some sense of historical consciousness as to how many issues that plague the contemporary philosophical problem of divine hiddenness as well as the defenses for theism cannot be said to have their origins in the traditions of the $\mathrm{HB}$ as a whole. Not that they must or could, but awareness of what from certain ancient Israelite perspectives turn out to be pseudo-concerns in Schellenberg and company's philosophical approaches to divine hiddenness might allow for less possible misconceptions as to the alleged roots of the problematic in the HB itself.

One result of the study, however, would then be that philosophers of religion, whether Christian or atheist, cannot so easily appeal to the $\mathrm{HB}$ as a foundation for their thinking, as though it was a text with a coherent set of concerns and conceptions identical to those of people today. Whilst a case could be made for some points of agreement between past and the present assumptions related to divine hiddenness, this introductory comparative assessment demonstrated some decisive and notable differences in the respective conceptual backgrounds, thereby ruling out a 'biblical' construction of the philosophical argument.

Ultimately, though this might be taken by some to imply that dialogue between the two disciplines of HB studies and philosophy of religion is not a viable way forward and that each must stand with its own integrity, this was not the intention. The point was merely to clarify areas with the potential for misunderstanding and presumption, and in this way offer a useful contribution at the interface of what has in the past been, but need not be, two very different fields of study.

\section{Acknowledgements Competing interests}

The author declares that he has no financial or personal relationships which may have inappropriately influenced him in writing this article.

\section{References}

Aijaz, I. \& Weidler, M., 2007, 'Some critical reflections on the hiddenness argument', International Journal for Philosophy of Religion 61, 1-23.

Albertz, R., 1994, History of Israelite religion, trans. J. Bowden, Westminster/John Knox, Louisville, KY.

Balentine, S., 1983, The hidden God: The hidden of the face of God in the Old Testament, Oxford University Press, Oxford.

Brueggemann, W., 1997, Theology of the Old Testament: Testimony, dispute, advocacy, Fortress Press, Philadelphia.

Crenshaw, J.L. 2005, Defending God: Biblical responses to the problem of evil, Oxford University Press, Oxford.

Davidson, R., 1983, The courage to doubt: Exploring an Old Testament theme, SCM Press, London.

Dougherty, T. \& Poston, T., 2007, 'Divine hiddenness and the nature of belief', Religious Studies 43, 183-198.

Drange, T., 1998, Nonbelief \& evil: Two arguments for the nonexistence of God, Prometheus Books, Amherst.

Fretheim, T.E., 1982, The suffering of God, Fortress Press, Philadelphia.

Frevel, C., 2013, 'Beyond monotheism? Some remarks and questions on conceptualizing "monotheism" in Biblical Studies', Verbum et Ecclesia 34(2), Art \# 810. http://dx.doi.org/10.4102/ve.v34i2.810

Gericke, J., 2012, The Hebrew Bible and philosophy of religion, Resources for Biblical Study 70, Society of Biblical Literature Press, Atlanta.

Gerstenberger, E.H., 2002, Theologies of the Old Testament, transl. J. Bowden, Fortress Press, Minneapolis.

Howard-Snyder, D., 1996, 'The argument from divine hiddenness', Canadian Journa of Philosophy 26, 433-453.

Howard-Snyder, D. \& Moser, P.K. (eds.), 2001, Divine hiddenness: New essays, pp. 7-9, Cambridge University Press, Cambridge.

Lehe, R., 2004, 'A response to the argument from the reasonableness of nonbelief', Faith and Philosophy 21, 159-174.

Leuenberger, M., 2011, 'Gott in Bewegung, Religions- und theologiegeschichtliche Beiträge zu Gottesvorstellungen im alten Israel', Forschungen zum Alten Testament 76, Mohr Siebeck, Tübingen.

McKim, R., 2001, Religious ambiguity and religious diversity, Oxford University Press, Oxford.

Murray, M.J. \& Taylor, D.E., 2010, 'Hiddenness', in C. Meister \& P. Copan (eds.), The Routledge companion to philosophy of religion, pp. 308-317, Routledge, London.

Perlitt, L., 1971, 'Die verborgenheit Gottes', in H.W. Wolf (ed.), Probleme biblische theologie, pp. 367-382, Christian Kaiser Verlag, Munich. 
Sæb $\varnothing$, M., 2000, 'Yahweh as Deus absconditus: Some remarks on a dictum by Gerhard von Rad', in D. Penchansky \& P.L. Redditt (eds.), Shall not the judge of all the earth do what is right?: Studies on the nature of God in tribute to James L. Crenshaw,
pp. 43-55, Eisenbrauns, Winona Lake.

Schellenberg, J.L., 1993, Divine hiddenness and human reason, Cornell University Press, Ithaca.

Schellenberg, J.L., 2004, 'Does divine hiddenness justify atheism?', in M.L. Peterson \& R.J. van Arragon (eds.), Contemporary debates in the philosophy of religion, pp. 30-41, Blackwell, London.

Schellenberg, J.L., 2005a, 'The hiddenness argument revisited (I)', Religious Studies 41, 201-215.

Schellenberg, J.L., 2005b, 'The hiddenness argument revisited (II)', Religious Studies 41, 287-303.

Schellenberg, J.L., 2005c, 'On reasonable nonbelief and perfect love: Replies to Henry and Lehe', Faith and Philosophy 22, 330-342.

Schellenberg, J.L., 2010a, 'The hiddenness problem and the problem of evil', Faith and Philosophy 27(1), 45-60.
Schellenberg, J.L., 2010b, 'Divine hiddenness', in C. Taliaferro, P. Draper \& P. Quinn (eds.) A companion to philosophy of religion, 2nd edn., pp. 509-510, Wiley-Blackwell, London.

Schellenberg, J.L., 2011, 'Would a loving God hide from anyone?', in R. Solomon \& D. McDermid (eds.), Introducing philosophy for Canadians, pp. 165-166, Oxford University Press, Oxford.

Sommer, B.D., 2009, The bodies of God and the world of ancient Israel, Cambridge University Press, New York.

Terrien, S., 1978, The elusive presence: Towards a new biblical theology, Harper \& Row, New York.

Tucker, C., 2008, 'Divine hiddenness and the value of divine-creature relationships', Religious Studies 44, 269-287.

Van der Toorn, K., 1999, 'God (I)', in K. van der Toorn, P.W. van der Horst \& B. Becking (eds.), Dictionary of deities and demons in the Bible, pp. 353-366, Brill, Leiden.

Van der Toorn, K., Van der Horst, P.W. \& Becking, B. (eds.), 1999, Dictionary of deities and demons in the Bible, Brill, Leiden. 